Preprint of conditionally accepted manuscript. Forthcoming in Gender \& Society. 2020-09-21 Web version.

\title{
Hybrid Femininities: Making Sense of Sorority Rankings and Reputation ${ }^{1}$
}

\author{
Simone Ispa-Landa ${ }^{2}$ and Mariana Oliver ${ }^{3}$
}

\begin{abstract}
Gender researchers have only begun to identify how women perceive and explain the costs and benefits associated with different femininities. Yet, status hierarchies among historically white college sororities are explicit and cannot be ignored, forcing sorority women to grapple with constructions of feminine worth. Drawing on interviews with women in these sororities $(\mathrm{N}=53)$, we are able to capture college women's attitudes towards status rankings that prioritize adherence to narrow models of gender complementarity. Sorority chapters were ranked according to women's perceived heterosexual appeal to elite men. Women believed that topranked sororities conferred social power while middle-and bottom-ranked sororities offered greater freedom from policing over members' bodies, fashion, and socializing. However, middle- and bottom-ranked sororities sometimes sought to rise in the rankings. When this occurred, existing members were marginalized, and a new pledge class with a greater tolerance for socializing with high-status "rapey" fraternities was sought. Women's discussions of sorority rankings show evidence of a hybrid femininity that fuses practices from traditional models of gender complementarity and more recent models of women's empowerment.
\end{abstract}

\footnotetext{
${ }^{1}$ We thank the college women who shared their time and experiences with us. We also thank Sara Thomas for her invaluable contributions and Freeden Blume Oeur, Barbara Risman, Elizabeth A. Armstrong, Jonathan Guryan, and anonymous reviewers at Gender \& Society for insightful feedback.

${ }^{2}$ Simone Ispa-Landa is Associate Professor at Northwestern University, Department of Human Development and Social Policy and (by courtesy) Sociology.

${ }^{3}$ Mariana Oliver is a PhD and JD student at Northwestern University, Department of Sociology and Pritzker School of Law.
} 
Preprint of conditionally accepted manuscript. Forthcoming in Gender \& Society. 2020-09-21 Web version.

\section{Hybrid Femininities: Making Sense of Sorority Rankings and Reputation}

A great deal of gender scholarship focuses on how women are subordinated to men (Connell 1987), and a growing body of research examines how men may be subordinated to other men (Connell 1995; Messerschmidt 2016). Bridges and Pascoe (2014) have shown that men may create "hybrid masculinities" as they combine elements from diverse masculinities and seek to displace newly stigmatized elements (like overt misogyny) with more progressive ones (like interest in childrearing). However, scholars have yet to address the similar question of how socially advantaged women might combine elements of different and sometimes conflicting models of femininity. In this article, we join an emerging body of research that places analytic attention on how multiple femininities exist in relation to one another (Hamilton et al. 2019). Our analysis focuses on how college women at a highly selective university negotiate and manage a social status system that aligns with traditional models of gender complementarity (models in which men and women are seen as necessarily different, with unequal but complementary interests and roles; Hamilton 2014). Presumably, these college women hold some attitudes taken from gender-egalitarian models (Risman 2018). Further, they may wish to distance themselves from aspects of traditional femininity that have become increasingly stigmatized in today's context, such as willingness to accept male domination, lack of career ambition, or a superficiality born of class-privileged distance from necessity (Renold \& Allan 2006).

We examined interviews with 53 women in historically white sororities at "Central," a pseudonymous North American university. Building on past research on hegemonic femininities (Connell 1987; Hamilton et al. 2019), we ask how women make sense of a sorority ranking and reputation system that aligns with traditional models of hierarchical and complementary gender relations (Ispa-Landa 2013; Schippers 2007). Within this context, women must contend with 
Preprint of conditionally accepted manuscript. Forthcoming in Gender \& Society. 2020-09-21 Web version.

sexist discourses that circulate about sorority women, including media characterizations of sorority women as "displaying too much femininity" (Graber and Whipple 2019: 8). We use women's discussions of the sorority ranking and reputation system to theorize how they construct their femininities.

Sororities are an ideal site from which to examine how women negotiate femininities and gendered power for several reasons. First, women's power relative to men is reduced through official as well as unofficial rules. Sororities are officially banned from serving alcohol at parties, while fraternities are not. Thus, fraternities, not sororities, tend to host parties (DeSantis 2007) where women are guests on men's turf. Men dominate and control most aspects of the party, including the types and quantity of alcohol (Armstrong, Hamilton and Sweeney 2006, Wade 2017). Within this male-controlled space, women are expected to "serve and perform for men" (Jozkowski and Wiersma-Mosley 2017: 92). Second, unlike most contemporary workplaces, families, or schools, there is an explicit hierarchy of women's feminine worth, enabled and made visible through a tier system (DeSantis 2007). Even if women wish it were not so, rankings of women's worth based on traditional models of gender complementarity are both acknowledged and agreed-upon. Women in the top tier are seen as the most desirable to men, active on the party circuit, and wealthy. Those characteristics are believed to be progressively less descriptive of women in the middle and bottom tiers.

Gender researchers have only begun to to identify how women perceive and explain the costs and benefits associated with different femininities. In most settings where femininities have been studied - at work, in the home, and the classroom or school - women are disempowered through covert means, and stratification based on heterosexual appeal is concealed or unacknowledged. In Greek life, by contrast, power asymmetries with men and hierarchies 
Preprint of conditionally accepted manuscript. Forthcoming in Gender \& Society. 2020-09-21 Web version.

among women are explicit and cannot be ignored. Women must find ways to make sense of and navigate them.

We confirmed the existence of a system of formally produced gender inequality between women and men and among women. Then, we capitalized on its existence to probe women’s sensemaking about what could be gained and lost from belonging to its different status categories. Our study opens a window into the tensions that arise as college women who have embraced some elements of egalitarian gender models negotiate a social system in which status criteria are rooted in traditional models of gender complementarity. We find evidence of a hybrid femininity that fuses practices from traditional models of gender complementarity and more recent models of women's empowerment. Fusing elements of these two models created ambivalence that was evident in women's discussions of a sorority ranking system that aligned with traditional models of gender complementarity. In this paper, we leave the question of how sorority women make sense of the historical and ongoing racial dynamics within historically white Greek life largely untouched. For a study that delves into that topic, see Hughey (2010).

\section{FEMININITIES AND GENDERED POWER}

Much of our current theorizing about femininities grew out of Connell’s (1987) Gender \& Power. Following Connell (1987), scholars have argued that affluent, white, heterosexual women can draw on hegemonic femininities, rooted in traditional gender complementarity models, to dominate others, including other women and men (e.g., Bettie 2003; Collins 2000; Connell 1987; Hamilton et al. 2019; Myers 2014). Although they remain in a subordinate position vis-à-vis elite men, elite women with hegemonic femininities, or "the most celebrated cultural ideals of womanhood in a given time and place" (Hamilton et al. 2019: 322), enjoy a "femininity premium" (316). The femininity premium includes increased chances of acquiring male partners who can provide social and economic benefits and power over other women. However, there are also steep costs 
Preprint of conditionally accepted manuscript. Forthcoming in Gender \& Society. 2020-09-21 Web version.

to performing hegemonic femininities_a femininity tax (ibid, p. 330). These include

psychological and physiological disorders associated with an intense focus on appearance and reputation, including eating disorders, anxiety, and depression. Another femininity tax involves knowing that one's advantages are accumulated along axes that disadvantage the group (e.g., a young, thin blonde woman benefits from a system that disadvantages women as a collective). In sum, the femininity premium confers unique advantages and comes with particular costs, and it is inextricable from high-status women's subordinate relationship to elite men (Hamilton et al. 2019). The concept improves understanding of why high-status women consent to participate in systems where they are disadvantaged vis-à-vis men. Sororities are one location believed to disadvantage women in this way (DeSantis 2007; Hirsch \& Khan 2020; Stuber, Klugman \& Daniel 2011; Wade 2017).

Hamilton et al. (2019) also build on important work by Collins (2000) in their description of intersectional domination, a process in which "people draw on their social location-not just in race and class, but also in gender-as a source of power over other individuals and social groups (ibid, p. 316)." The concept of intersectional domination dissolves a simplistic and binary paradigm that focuses solely on men's aggregate domination over women (see also Bettie 2003; Choo \& Ferree 2010; Collins 2000), offering researchers an additional tool for understanding hierarchies and power relations among women and femininities. As with relational theories of gender (e.g., Ispa-Landa 2013; Schippers 2007), the concept of intersectional domination posits that femininities are numerous and hierarchical, creating a social system in which many women struggle to achieve hegemonic femininity. However, while relational theorists attend to how femininities exist in a complementary and hierarchical relationship to masculinities, Hamilton et al. (2019) place analytic attention on how femininities exist in relation to one another. 
Preprint of conditionally accepted manuscript. Forthcoming in Gender \& Society. 2020-09-21 Web version.

The concept of intersectional domination also opens additional inquiry and theorization as to how women can benefit from hegemonic femininities and the price they pay for enacting it. As noted above, Hamilton et al. (2019) describe the advantages that amass to those who can skillfully perform hegemonic femininity as a "femininity premium" (p. 3; p. 20), and the costs a femininity tax. Because the matrix of domination (Collins 2000) does not place hegemonic femininity in the highest position, a femininity ceiling limits the benefits associated with performing it. For instance, it may be impossible for a woman to reach the ceiling of professional success while still retaining the highest femininity premium; the behaviors associated with hegemonic femininity will conflict with the behaviors associated with professional success. Rather than presuming that women are "cultural dopes" who suffer from false consciousness about gender and patriarchy, Hamilton et al. (2019) propose that the femininity premium motivates women to strive for hegemonic femininity, even when this occurs unconsciously. In the contemporary US, efforts to reap the femininity premium typically include attempts to appeal sexually to white heterosexual men and ally with elite men who control wealth and power. As women of color and women from lower social class backgrounds have less access to these possibilities, the femininity premium represents race and class privilege in a gendered form (Hamilton et al. 2019). Overall, Hamilton et al. 's (2019) conceptualization paves the way for new investigations of how privileged women can use femininity to influence, control, and exclude other women. Women who have the gender capital the "knowledge, resources, and aspects of identity" (Bridges 2009: 92) to skillfully embody hegemonic femininities often control other women's reputations and access to social networks.

The concept of hybrid femininities used in this paper builds on Bridges and Pascoe's (2014) concept of “hybrid masculinities.” They describe how socially advantaged men adopt and 
Preprint of conditionally accepted manuscript. Forthcoming in Gender \& Society. 2020-09-21 Web version.

combine elements from different masculine traditions. Researchers argue that hybrid masculinities allow privileged men to uphold their superior social positions in an era in which unearned privilege is stigmatized (Bridges and Pascoe 2014). The term "hybrid" is used because hegemonic masculinity "is not a purely white or heterosexual configuration of practice... it is a hybrid bloc that unites practices from diverse masculinities in order to ensure the reproduction of patriarchy (Demetriou 2001: 30)." Overall, hybrid masculinities combine practices from genderegalitarian and patriarchal models and allow privileged men to retain a sense of themselves as uniquely morally worthy and distinct from other men. We analyze whether and how an analogous process may unfold among similarly socially advantaged women.

\section{METHODS}

Women at Central rush in the winter of their first year of college and move into their sorority houses at the beginning of sophomore year. We wanted our first interviews with women to occur at a time when their impressions of rushing would still be fresh, and they would also have had the experience of being on the other side of rush as gatekeepers. Our goal was logical rather than statistical inference (Small 2009), so we were concerned with saturation, rather than with obtaining a sample that was representative of Central's sorority population.

Study recruitment. In the winter of 2017, we posted recruitment fliers offering $\$ 40$ gift cards to sophomore women in historically white sororities. Eighty-six women responded to our fliers; out of these, we interviewed all those who were eligible for the study based on their Greek membership and year in school, and who showed up to the interview. This led to a final sample of 37 sophomore women in Spring 2017 ("Cohort 1"). To dive deeper into our emerging findings, we used the same technique in Spring 2019 and recruited a second cohort of sophomore women ("Cohort 2") (n=16). Cohort 1 women were re-interviewed in Spring 2018 and 2019. 
Preprint of conditionally accepted manuscript. Forthcoming in Gender \& Society. 2020-09-21 Web version.

Cohort 2 participants have been interviewed once so far. Overall, our sample includes 53 participants (37 women from Cohort 1 and 16 women from Cohort 2), with 117 interviews in total. We gave pseudonyms to all 12 of the sorority chapters (Table 1 ) as well as to the women and the university. Sixty percent of the sample belonged to a middle-tier sorority, $21 \%$ to a bottom-tier sorority, and $19 \%$ to a top-tier sorority. ${ }^{4}$

Central is a highly selective private university with a fall 2018 acceptance rate of less than 10 percent. As at other highly selective universities, students from upper-class families are overrepresented at Central. Roughly 15 percent of students come from families whose earnings put them in the top 1 percent of the income distribution (over $\$ 630,000 /$ year). On the other side of the socioeconomic distribution, roughly 1 in 5 students are eligible for a Pell Grant. In 2011, the median family income for dependent Pell Grant recipients was $\$ 29,500$.

We were unable to obtain data on the socioeconomic backgrounds of Greek-affiliated women at Central, but in our interview sample of 53 women, 89\% reported that two parent/guardians had at least a 4-year college degree. Sixty percent of our participants selfidentified as White, compared to $71 \%$ of Central's sorority population and $48 \%$ of Central's overall undergraduate population. ${ }^{5}$ Twenty-three percent of our participants identified as Asian and 13 percent identified as LatinX. See Tables 2 and 3 for individual-level descriptive statistics for Cohorts 1 and 2.

\footnotetext{
${ }^{4}$ Participants were in broad agreement about which chapters belonged to the top, middle, and bottom-tiers at Central. We used these definitions to determine women’s tier placement. ${ }^{5}$ Central has a Multicultural Greek Council, separate from the PHA sororities, with majorityblack, Asian, and Latinx chapters.
} 
Preprint of conditionally accepted manuscript. Forthcoming in Gender \& Society. 2020-09-21 Web version.

Interviews. A team of five trained graduate students conducted one-on-one interviews. Members of the team met on a weekly basis to listen to and analyze audio recordings of the interviews; the goal was to ensure that all interviews would follow a similar semi-structured format, with sensitive follow-ups. The mean length of the interviews was 94.50 minutes. Interviews were recorded and transcribed. ${ }^{6}$

The initial research questions were broad: How does sorority recruitment reflect notions of feminine worth among women who were high-achievers in high school? How do women make sense of gender and class dynamics within sororities? Interviews covered several topics, including the decision to rush and satisfaction with various aspects of sororities. Interviews were designed to be loose and open-ended, allowing for participants' concerns to emerge and guide the conversation. Interviewers were trained to probe further when participants mentioned issues related to their own and others' gender performances, socioeconomic status, and sexual assault. The interview guide included questions like, "Did you expect to join a sorority at Central?" and "What would you say is distinctive about your sorority chapter?"

Ispa-Landa had never joined a sorority; neither had 4 of the 5 graduate student interviewers. They often had to ask participants to clarify and explain the organizational and social aspects of sororities. Although they may have initially missed the intended meaning of some of our participants' statements, their outsider status was also an advantage: they could credibly ask participants to "explain" and "teach us" about sorority life.

\footnotetext{
${ }^{6}$ We calculated the mean interview length from our wave 1 interviews, since women in both cohorts completed this interview. Five interviews (out of 53) were dropped from the calculation as we could not locate the audio files (but had the transcripts).
} 
Preprint of conditionally accepted manuscript. Forthcoming in Gender \& Society. 2020-09-21 Web version.

Flexible Coding. We followed the steps outlined in Deterding and Waters' (2018) recommendations for rigorous, flexible analysis of in-depth interviews within studies that are motivated by prior literature. Our first step was to create a database by indexing the interview transcripts with broad codes. Broad codes captured the questions from our interview protocol and the concepts we started the study with (Deterding and Waters 2018), including "gatekeeping" and "investment in heterosexual partying." As we applied these broad codes to our interview transcripts, we also wrote a memo on each participant that summarized and analyzed the main themes present in the interview with her. In setting up our database, we also linked transcripts to tier placement. This allowed us to compare conceptual themes by tier.

Analytic coding. As we indexed the transcripts, we added fine-grained codes (Deterding and Waters 2018) that reflected our deepening interest in women's perceptions of the femininity premium and tax; we also wrote an additional set of analytic memos that elaborated on main themes. Towards the end of this process, we compared our coding output for women in top-, middle-, and bottom-tier sororities and searched for exceptions. This process helped limit the scope of our claims (Deterding and Waters 2018). We used the QDA software program Dedoose to organize our analysis.

In what follows, we elaborate on our findings, presenting only those that were broadly represented among research participants. These data emerged primarily from participants' responses to follow-up questions, rather than to questions on the interview guide.

Because not all interviews elicited the same follow-up questions, we do not provide a breakdown of the number of response-types by theme or tier (see Small 2011 on the inappropriateness of frequency counts for many open-ended, conversational interview studies).

\section{HYBRID FEMININITIES}


Preprint of conditionally accepted manuscript. Forthcoming in Gender \& Society. 2020-09-21 Web version.

\section{Prioritizing academic achievement and heterosexual appeal}

Participants were aware of the negative imagery of women in sororities, particularly those related to images of frivolous, wealthy, blonde white women who care only about partying, fashion, and boys. Participants acknowledged that Greek life at Central was like Greek life at other universities in that it required and promoted interest in drinking and heterosexual partying. However, participants claimed that the academic and professional interests of sorority women at Central were a distinguishing mark. At times, participants cast sorority women at Central as embodying a distinct and superior form of femininity, one that combines partying and heterosexual attractiveness with academic success. As Jane explained, Sorority life at Central is different. It's got the tall blonde girls with the model proportions wearing Gucci and Vera Wang — they're wearing that, but they're still going out and doing cool things. Maybe they're presenting things at research conferences, or learning cool things, or discovering the next black hole, because they're at Central. That's just the kind of people we have here. So it's very different and had I been at any other school, I don't think I'd be in a sorority. (Jane, bottom-tier)

Apparently unaware of the race and class connotations of her remarks, Jane emphasized that in addition to conforming to conventional standards of white, class-privileged beauty, women at Central were also committed to academic achievement.

At other times, participants drew on putative distinctions between sorority life at Central and sorority life in the South to make a similar point. They characterized sororities at Central as distinct inasmuch as they allowed women to select among a wider range of ways of balancing heterosexual partying with career investment. As Claire explained, 
Preprint of conditionally accepted manuscript. Forthcoming in Gender \& Society. 2020-09-21 Web version.

In the South... the only type of people who do it [sororities] are... the ones that wanna spend every Saturday at the football game, always going out... and doing that 24/7, which some people at Central do, but a lot of people in Greek life at Central, including me... have a social life but also very much their academic and other activities life... At Central, the spread of types of people in Greek life is very wide (Claire, top-tier). Regardless of tier, research participants emphasized that sorority life at Central had a different character than the one found at most universities. They proudly drew on Central's reputation as an elite, highly selective institution to fortify a sense of themselves as superior to their female counterparts at other universities. Part of their claim was that sorority women at Central were able to maintain academic motivation while also conforming to conventional expectations that college women should prioritize their social lives and looks (Armstrong and Hamilton 2013). 'This is a place where you're building confidence within yourself'

Women in all the tiers claimed that, during recruitment, they were looking for confident women who could successfully convey that they were motivated to join a sorority because they were looking for a "girl power" kind of environment - a place where women felt emboldened to proclaim their unique interests, talents, and enthusiasms. Accordingly, rushees had to downplay the Greek system's emphasis on sorority/fraternity mixers and pairings. It was considered gauche to portray oneself as motivated to join a sorority out of an interest in partying with fraternity men. As Sandra explained, her chapter sought to recruit women who could articulate a commitment to helping other women build confidence in themselves and their relationships with other women:

I think if they're [rushees] asking a lot about who we mix with and interactions with fraternities, if those are your main questions, then this is not the place for you. 
Preprint of conditionally accepted manuscript. Forthcoming in Gender \& Society. 2020-09-21 Web version.

Confidence is the core of what [chapter name] is, so we're not here to introduce you to that cute [fraternity name] (top-tier fraternity) boy. (Sandra, middle-tier)

Sandra and other women were describing a new cultural ideal for race and class-privileged femininity - that of the outspoken, driven, career-committed woman who downplays her own interest and investment in appealing to elite men. Rushees had to have the cultural capital to understand that the desire to mix with fraternities was not to be openly discussed during recruitment.

\section{Outrage and resignation about gendered power asymmetries}

Participants expressed outrage regarding the patriarchal structures within Greek life, especially as they pertained to sexual assault. Women described the setup of both mixers and open parties (parties hosted by fraternities and open to the entire campus) as predatory. As Brianna stated,

Literally, frats invite women into their home and they decide [who gets in] based on appearance. It's a loud basement where it's hard to talk and so you either dance or you whisper. You have to get really close to talk to somebody. It feels predatory and almost like it's constructed for that purpose, the whole setup of it." (Brianna, middle-tier) Brianna's statement that fraternity parties seemed designed to promote male sexual predation was unusual for the sample in that she implied there was intentionality involved. However, almost all of the women in our sample complained about the prevalence of sexual assault at fraternity parties. Most argued that the best solution would be for Panhellenic Association, the national governing body for all historically white sororities, to allow sororities to host parties, as this would give women greater control over the environment. 
Preprint of conditionally accepted manuscript. Forthcoming in Gender \& Society. 2020-09-21 Web version.

Women in all tiers were aware of the sexism involved in Greek life; they articulated its dynamics clearly in interviews and expressed frustration about their inability to change it. As Arshia explained,

These inequalities between fraternities and sorority are crazy to exist. It's 2019! Why is it that fraternities are allowed to have alcohol and sororities aren't, so the only way for people in sororities to gain access to alcohol is to go to mixers and it puts them at risk? Every year, there's a sexual assault story that... rocks the Greek life world. It's a recurring theme. (Arshia, bottom-tier)

Women in sororities at Central were not blind to the patriarchal nature of Greek life. However, throughout their accounts, there was little to suggest that they saw change on the horizon; a clear note of resignation ran through their narratives about sexual violence in Greek life.

Women enjoyed the validation that came from approaching traditional cultural ideals of femininity. This was true even though they also resented the fact that this validation was rooted in hierarchical gender relations and clashed with their progressive ideals. For instance, Zora told a story that featured outward repudiation of male domination. However, a sense of emotional gratification at elite men's occasional approval peeked out of the story, suggesting a more complicated account. As Zora stated,

My sorority scheduled a bunch of mixers with FIK (a top-tier fraternity) and they always cancel on us. It's a running joke like, 'Oh, we're not top-tier, so they don't want to mix with us,' but what I realized about the tier system is it's so stupid and usually the guys at the top are assholes.

INT: Why do you think it is that guys play such a huge role in it? 
Preprint of conditionally accepted manuscript. Forthcoming in Gender \& Society. 2020-09-21 Web version.

I think men have this influence over women, and women need to impress them in a way, and girls-I see people who go out, and I'm included in that, and don't wear any clothes, like wearing a crop top that shows my boobs. I want to impress the boys. I'm very, 'fuck the patriarchy,' but it's that feeling, like when Gray [a top-tier sorority] asked me back [during recruitment], I was like, 'Wow, I'm so cool.' When a top-tier fraternity recognizes you, you're like, 'Wow, we're so cool.' There's something about the power that men have. (Zora, middle-tier)

Zora linked the feeling of elation and pleasure at being asked back to Gray, the top-tier sorority from which she was eventually cut, to the feelings that she and other members of her sorority experienced when they felt "recognized" by members of a top-tier fraternity. It is not surprising that Zora linked the two situations: both are rooted in social recognition for approaching the traditional cultural ideal of womanhood. These positive emotions are also entangled with women's participation in a male-dominated status hierarchy.

Same expectations, different intensities: Perceptions of the tier system. Women's portrayal of the three top-tier chapters emphasized traits that suggested that entrée into them required a heightened performance of hegemonic femininity, compared to the femininity needed to be accepted into a middle- or bottom-tier chapter. Being in a top-tier chapter meant being recognized by others as conforming to the new feminine ideal of "having it all" -- academic achievement, white heterosexual appeal and wealth, and intense partying. Allison explained, Sororities are on a scale... I think everyone's [in the Greek system] academic. But the top-tier sororities are the richest girls, the girls who can afford expensive things. Of course there's exceptions, but typically they are more white or blonde... And attractiveness has a huge role in it, if your body type -- if you work out, if you maintain 
Preprint of conditionally accepted manuscript. Forthcoming in Gender \& Society. 2020-09-21 Web version.

certain things... Basically, top-tier sororities are the most stereotypical college sororities. They drink a lot, they party a lot, they are at frat houses a lot... Low-tier -- they're not the typical sorority or fraternity... They're not as selective- they don't have a standard of how to look or how much money you have... .And then mid-tier just falls somewhere along that gradient. (Allison, bottom-tier)

Regardless of their own sorority house's tier placement, women's portrayals of the top, middle- and bottom tier chapters were similar. For instance, Flora belonged to a top-tier sorority. But like Allison, she identified the tier system as a hierarchy that sorted women by looks, fashion sense, and interest in partying. As Flora explained,

People say that Pink [a middle-tier sorority] girls are pretty, and all three [top-tier] sororities - they go out a lot. And then there's some at the bottom that are nice, but people said they were awkward. Besides the top ones, the other ones tend to be-they're not really sorority girls, they're just a group of girls that know each other. You don't get the sorority feel from them.... But the top ones are people who like to go out and typically dress nice, and [have the] appearance. (Flora, top-tier)

The differences between top and bottom-tier chapters that Flora and Allison described align with scholarly understandings of hegemonic femininity, which include race and class privilege, intensive investments in a conventionally attractive appearance, and interest in heterosexual partying (Bettie 2003; Collins 2000; Connell 1987; Hamilton et al. 2019). These differences are also consistent with Khan's (2010) notion of a "sexuality regime" that assigns value to women along a single dimension (their conventional femininity and heterosexual attractiveness). Flora and Allison did not describe a heterarchy, or a system that provides "multiple hierarchies of worth" (Lamont 2012: 202). 
Preprint of conditionally accepted manuscript. Forthcoming in Gender \& Society. 2020-09-21 Web version.

In sum, we found consensus among women in top-, middle-, and bottom tier sororities about the tier system and the distinct nature of sororities in each of the tiers. Depending on where their sorority ranked in the tier system, women also expressed unique concerns. These tierdependent experiences and concerns are linked to the competitive, hierarchical nature of the tier system and the hegemonic feminine ideal that undergirds it.

\section{Being Top-Tier}

Women in top-tier sororities enjoyed social power over other women and exclusive access to men in top-tier fraternities. This femininity premium was guaranteed by social closure: top-tier sororities and fraternities mixed only with each other. In addition, recruitment processes ensured that only a particular "type" of woman would be admitted to top-tier sororities. As Lea explained,

All the girls in my sorority are really pretty. Like, beautiful in a powerful way with men and also in a way that intimidates other women... It's pretty girls with big personalities and a lot of social power. It's like, are we making other women feel secure in themselves, or are we only supporting this power structure between women? Um, because it [sorority life] is competitive and you can hear derogatory comments about people from certain chapters, which is not the feminist ideology that we supposedly support. (Lea, top-tier) For young, affluent women like Lea, a femininity tax may include unease about one's superior position in race, class, and gender hierarchies. Lea was uncomfortably aware that she and the other women in her top-tier sorority were complicit in disempowering other women. Past research shows a parallel unease among socially advantaged men (Bridges and Pascoe 2014); here, we uncover it among women who sit atop of peer status hierarchies. 
Preprint of conditionally accepted manuscript. Forthcoming in Gender \& Society. 2020-09-21 Web version.

At other times, women in top-tier sororities expressed discomfort about their sorority chapters' superior social position but without explicitly linking their discomfort to their role in perpetuating the hierarchy and putting other women down. For instance, when asked to describe the tier system, Natalie was blunt in saying it is "a ranking of average good looks, compounded by will girls show up to parties, and... have fun and drink... and not just be silent and introverted." Natalie did not explicitly describe differences among women in terms of a "power structure" like Lea. However, she still showed discomfort about inequalities across tiers:

There's a thing where mixers between different tiers -- those [barriers] are real. I keep saying, "It's real," because a lot of what I heard when I was a rushee was, "Oh no, it's not real. There's not a real tier system." And you're like, "Shit, they're telling me it's not real, but I know it is." There’s some reason there’s a ranking. That being said, is it [the ranking] important? Yes and no. Um, is it easier for some people to have flourishing social lives if they're in a top house? Yes, but it's not an inflexible rule of law... I feel like I sound really patronizing, but um -- that [not-being top-tier] doesn't end them [socially]. (Natalie, top-tier)

Natalie found PHA's official denial of the existence of the tier system hypocritical given the obvious differences in opportunities it afforded to women in different tiers. Yet, she went back and forth about whether a sorority’s ranking was important. Like Lea, Natalie seemed uncomfortable with the idea that she sat atop of status hierarchy that denied some women the social opportunities that she enjoyed.

At other points in the interviews, participants denied receiving benefits from belonging to a top-tier sorority. At these times, women acknowledged the tier system's influence and power but claimed it didn't matter for them personally. 
Preprint of conditionally accepted manuscript. Forthcoming in Gender \& Society. 2020-09-21 Web version.

In sum, the inconsistent narratives of women in top-tier sororities gave the impression of a lack of ease regarding the tier system that conferred advantages on them. Sometimes, women openly acknowledged this discomfort; at other times, they sent mixed messages about the role of the tier system in their lives.

\section{The Middle-Tier Sorority Experience}

As noted above, the tier system represented a hierarchy where women were ranked according to a single set of criteria. Underscoring this fact, women in middle-tier sororities described their chapters as less cool than top-tier sororities. They also believed their chapters to be less demanding than top-tier houses in their expectations of women's beauty, fashion sense, and partying. Ruth, who said she didn’t identify as a “cool person,” explained that her middletier chapter was a better fit for her than a top-tier sorority because it matched her quieter socializing style:

I know in those [top tier] sororities they're typically cooler... like always up on the styles, and know what's going on, and know a lot of people. And I don't know if I would describe myself as cool. That's not coming from a bad place, it's just, I'm more the type of person who has a few close friends and will dedicate my time to them - it's just a different social vibe. (Ruth, middle-tier)

Ruth did not appear to feel bad about her socializing style; she merely acknowledged that, as an introvert, a top-tier sorority’s expectations for partying would be excessive.

Melody seemed to caution that top-tier sororities might want too much of their members, pressuring them to conform to an image that would feel inauthentic. As she stated,

I would advise them (rushees) not to think about it as a tier. You should want the houses... based on who you talked to, and not what you think you're supposed to want, 
Preprint of conditionally accepted manuscript. Forthcoming in Gender \& Society. 2020-09-21 Web version.

based on what the people around you think -- like [choose the place] where you think you would be most comfortable being on your laziest day or you're wearing sweatpants and you don’t wanna talk to anyone that frustrates you. (Melody, middle-tier)

Melody felt that rushees should aim for a sorority placement where the expectations for appearance and interaction would feel comfortable. She was aware that it would be hard for rushees not to strive for a spot in a top-tier sorority, given that people generally assumed this was the goal of rush. Melody's comment reveals an acute familiarity and understanding of the femininity premium and tax: she knew there was a tradeoff between achieving status and power as a woman, and being able to enjoy a comfortable existence that did not involve constant body policing and effort to live up to a narrow and restrictive feminine ideal. Achieving hegemonic femininity is never "complete” and involves ongoing effort and strain; it is a deeply felt femininity tax (Hamilton et al. 2019).

Overall, in our study, we have evidence that women may strategize to avoid paying a very high femininity tax by selecting all-female groups where the beauty and behavior standards are lower or less heavily policed. However, a middle-status group of women can always decide to police beauty standards more intensely, especially if they believe that doing so will raise their collective status.

According to our participants’ reports, at least three of the six middle-tier sororities (Orange, Pink, and Violet) had attempted to move up in the tier system in the past few years. As mixing with top-tier fraternities was evidence of high status and a creator of it, women reported 
Preprint of conditionally accepted manuscript. Forthcoming in Gender \& Society. 2020-09-21 Web version.

that a sorority could move up in the tier system by recruiting a pledge class that would be more attractive to men in top-tier fraternities. ${ }^{7}$

Recruiting a pledge class that would be more attractive to men in top-tier fraternities required careful strategizing on the part of the recruitment chair. (During rush, a recruitment chair is responsible for assigning members to the "bump," or rotation groups that ensure that rushees will meet the right combination of members in their short tour of the sorority chapters). Recruitment chairs were said to "hide" members who they believed would represent the house poorly, either because they were seen as socially awkward or physically unattractive and unfashionable.

Women who had been "hidden” or who were assigned to few bump groups linked the experience to their chapters' attempts to move up in the tier system. Chloe burst into tears as she described how she had not been paired with many rushees:

I had a hard time with recruitment this year, because... of the targeted people that they wanted... I was never paired with any of the girls. It's hard not to take it personally, because it was so personal. I talked to maybe two rushees and I'm there for the whole day - and it's like, 'if you don't want me there that's fine, just tell me,' but they were like, 'it was a mistake, it was an oversight.' But it’s not a mistake - you put so much time and effort into planning this [recruitment], it's not a mistake. I'm not stupid. It was very obvious that they just didn’t want more backpack [Oranges]. They want to move the stereotype of [Orange] differently.

INT: And what is the stereotype now?

\footnotetext{
${ }^{7}$ Moving up in the tier system was neither universally desired by women in middle-tier sororities; nor was it uncontroversial within the chapters that attempted it.
} 
Preprint of conditionally accepted manuscript. Forthcoming in Gender \& Society. 2020-09-21 Web version.

The stereotype now is very girl-next-door... And they’re trying to move the stereotype...

trying to copy [a top-tier house], trying to move up. (Chloe, middle-tier)

Chloe felt harmed by her chapter's attempts to rise in the rankings. Her description of her chapter's reputation as the "backpack Oranges" evoked the middle-of-the-road image that it was trying to shed - an image that Chloe identified with. Backpacks are unisex, not feminine; they are associated with school and work, not parties; and they are utilitarian rather than decorative. In the end, Chloe was devalued and said she wished her sorority chapter would stop trying to be “something we are not.”

Rose reported that her sorority had recruited a pledge class that was believed to be more attractive than her pledge class. She attributed increased tension to the change:

Some of our new girls were starting to think we're super hot and fraternities are like 'yes, now this is what we're after.' Which is fine, I don't care if everyone thinks we're hot, but that's not why people come... Like we do not get people in our sorority for being attractive, we get them for being cool people. It made me really uncomfortable because I did not go into a sorority to be in the hot sorority that all the boys want. I wanted to be in a sorority to find a bunch of girls who can be my friends. (Rose, middle-tier)

For Rose, female friendship and closeness were threatened by a new pledge class, which entered the sorority with a greater emphasis on appealing to men in top-fraternities. The more attention Rose’s sorority began to garner from fraternities, the more distant and uncomfortable she felt.

Compared to women in top-tier sororities, women in middle-tier sororities believed that they enjoyed freedom from less stringent standards of beauty, fashion, and socializing. In their view, this allowed them to experience greater comfort, camaraderie, and authenticity with their women friends. Women in middle-tier sororities also reported they could socialize with men in a 
Preprint of conditionally accepted manuscript. Forthcoming in Gender \& Society. 2020-09-21 Web version.

broader range of fraternities, expanding their romantic and sexual options. On the flip side, our analysis suggests that women in middle-tier sororities confronted specific jeopardies and temptations, as their group could always attempt a rise in status. This process put some women at risk of being excluded and marginalized from the group.

The Bottom-Tier Sorority Experience

Women in bottom-tier sororities rejected the idea that the tier system reflected their worth. However, their comments also implied a belief in the legitimacy of ranking a sorority by its reputation for "going out” and being able to attract the attention and interest of fraternity men. Pearl, a white woman in a bottom-tier sorority, began using air quotes when she started describing the tier system:

The tier system is mainly based on looks. Also there's a stereotype of who are the really rich people, and they'll be in the top tier. And sororities with [mocking tone, air quotes] pretty, popular girls are on top and mix with fraternities that have hot popular boys [laughs].

Int: And who determines what tier a sorority is in?

The fraternities. Like, in my chapter we talk about how dumb it is. I don't know if other chapters talk about it, but it's something that everyone is very aware of.

Int: Yeah, and what kinds of things do you guys criticize about it?

Just how patriarchal it is [laughing]. Basically.

Int: And what's your tier?

I'd say we're bottom tier, but at the top of the bottom, because like-we don't party all the time, and we mix with middle to lower-tier fraternities. We still are cool, and go out. (Pearl, bottom-tier) 
Preprint of conditionally accepted manuscript. Forthcoming in Gender \& Society. 2020-09-21 Web version.

Pearl made fun of the tier system and criticized the sexism inherent in it. Yet, her comment that her sorority was at the "top of the bottom tier" revealed concern about where her sorority fell in the tier system.

Like women in middle-tier sororities, women in bottom-tier sororities emphasized their appreciation for being in a sorority that did not hold them to unrealistic, high-effort beauty standards. As Amy explained,

I live in the house and so I'll go downstairs and I look like crap, I'm wearing sweatpants and a T-shirt and my hair's a mess and I'm not wearing any makeup and my friends downstairs, they’re still really excited to see me and they're not even my closest friends, but I know I can go downstairs and anyone who’s there will be happy to talk to me and hang out with me. (Amy, bottom-tier)

Amy’s comments highlight the relief that women in lower-tier sororities experienced when, contrary to their expectations, they found they did not have to cope with negative judgments about their looks from other women.

Sally emphasized that being in the top-tier sorority might not even be desirable, given all the work it entailed and the fact that it might not even be "comfortable.” As she explained, A lot of people didn't seek out to be in top tier 'cause they wouldn't even feel comfortable... those [top tier] are stereotypically cool people. They're trying really hard to keep up this appearance. Like one of my friends, she had [the potential to try for Brown]... But she didn't feel like she would fit in... there's the expectation that you have to try really hard... or... be very popular and... it seems like more effort and not as natural.... If you feel like you have to keep up with that appearance, that might be exhausting. (Sally, bottom-tier) 
Preprint of conditionally accepted manuscript. Forthcoming in Gender \& Society. 2020-09-21 Web version.

Sally portrayed top-tier sororities as demanding sites of labor, places where all one's effort and attention would be consumed by the need to maintain a particular image and appearance.

Only one woman in a bottom-tier sorority, Leslie, admitted that her chapter hoped to rise in the rankings. Leslie's account was disturbing: she tied members' desire to improve the chapter's ranking to members' unwillingness to boycott mixers with higher-status fraternities who had been accused of sexual assault. Leslie found this incongruent with her chapter's philanthropic focus on domestic violence. As she explained,

Everyone's mad (about recent sexual assault allegations involving top-tier fraternities). But honestly, I had hoped that since our chapter was the domestic violence awareness chapter and we do so much to bring awareness to sexual assault that we would do something bigger... like, say we're not mixing with frats until this is all cleared up... but we just waited until the social ban (a penalty imposed by the university) was over and continued to have mixers with frats. Mostly everyone was just annoyed by the social ban. I think there's older members who have graduated who were more feminist but my class, they are trying to improve our rep and they're trying to promote mixing with frats. So they're more willing to look the other way if that means they can get our sorority to move up to the middle tier. But if we really stood against campus sexual assault, we would stop going to the place where it happens. (Leslie, bottom-tier)

Leslie's comments show the dangers inherent in a system where status is hierarchically assigned, such as that associated with hegemonic femininity. The women in Leslie’s chapter appeared willing to risk their safety and self-avowed feminist principles for the possibility of shedding their low status. 
Preprint of conditionally accepted manuscript. Forthcoming in Gender \& Society. 2020-09-21 Web version.

\section{CONCLUSION}

This papers builds upon previous work on processes of intersectional domination among women (Bettie 2003; Collins 2000) by analyzing these dynamics within a context where women are explicitly hierarchically ranked. As researchers, we capitalized on the existence of a formalized ranking system to uncover how, proclamations of feminist consciousness notwithstanding, status differences among sorority women continue to reflect perceptions of their worth within a system that values women primarily for heterosexual beauty and participation in male-controlled party spaces. Women portrayed all women in sororities at Central as academically ambitious and career-oriented; the difference between women in the toptier sororities and those in the two lower tiers lay in top-tier women's heightened investment in appearance and heterosexual partying. Our findings also contribute to theory-building about the Greek system. Past research identified a tiered Greek system at a large, public research university (DeSantis 2007); we extend this line of research by theorizing the sorority tier system as a reflection of hierarchies of feminine worth within a system that prioritizes gender complementarity.

We demonstrate the presence of a hybrid femininity that combines elements of traditional hegemonic femininity and more recent models of women's empowerment. Women’s sensemaking about the pros and cons of belonging to differently ranked sorority chapters reflected their fusion of these two elements. Indeed, women were keenly aware of the tradeoffs associated with the highest-status hegemonic femininity, something past researchers have been unable to uncover. Women were aware that membership in a top-tier sorority benefited women's social standing and offered exclusive access to social events with men in top-tier fraternities. However, they also pointed to the intense attention to appearance and partying that would be 
Preprint of conditionally accepted manuscript. Forthcoming in Gender \& Society. 2020-09-21 Web version.

required to gain acceptance in a top-tier sorority, and some claimed to be unwilling to bear these costs. Future research could examine how sorority women center whiteness and how this process overlaps with efforts to achieve hegemonic femininity.

Scholars of intersectionality have long drawn attention to the gendered processes through which elite women maintain race and class privilege and power (Collins 2000; Myers 2004). However, the rise of a new cultural ethos that stigmatizes unearned privilege calls for new strategies and justifications of privilege, especially among affluent, socially and politically aware young people (Bridges and Pascoe 2014). Our analysis uncovers how career commitment, devotion to heterosexual partying, awareness and frustration with gendered power asymmetries, and proclamations of distance from traditional femininity constitute a new form of hybrid femininity. To date, most inquiries into how young people manage their privilege have lacked a specific focus on women's gendered strategies. Indeed, past research has portrayed elite culture in largely gender-neutral terms (for a review, see Cousin, Khan, and Mears 2018). By contrast, our data show how elite college women draw on new class-specific versions of an achievementoriented, socially and politically aware, and heterosexually appealing feminine ideal.

Irrespective of which tier they were in, participants emphasized their desire to blend academic achievement with partying and heterosexual appeal within a broader cultural milieu that promoted women's confidence and ambition. Overall, our study suggests that hybrid femininities provide elite women with grounds for upholding their own achievement-oriented ideals of womanhood as superior to those of other women. This attitude is divisive; it stigmatizes traditional femininity and the women who are perceived to embody it.

Past research shows that the college Greek system plays a socioeconomically segregating role for students at selective universities, sequestering affluent students from their less 
Preprint of conditionally accepted manuscript. Forthcoming in Gender \& Society. 2020-09-21 Web version.

advantaged peers (Hamilton and Cheng 2018). This promotes a process wherein students' classbased resources are consolidated, rather than shared or "spilled over" in ways that could potentially benefit (or harm) less affluent students (ibid). Our findings show how, at an elite university, the tier system could create a similar kind of racial and socioeconomic segregation within Greek life because of how women's gendered and racialized class resources are deployed during recruitment. Future research with larger sample sizes could explore this possibility in greater depth.

For researchers whose interests lie at the intersection of gender, college peer cultures, and undergraduate education, it would be worthwhile to investigate connections between sorority women’s investment in academics and sorority involvement. Past research shows that many men in selective colleges began to spend more time on academics, and less time on social pursuits as they progress through college. By contrast, women’s time use remains consistently highly academic throughout college (Quadlin 2016). It seems plausible that, as sorority women advance in college, they - like many men - may become more concerned about their academic success and potential career development (Quadlin 2016). Yet, sororities are “greedy institutions” (Coser 1974): they seek undivided commitment and loyalty from members. Tracing sorority women’s commitments to sorority life and academics could reveal important shifts in college women’s calculations of the costs and benefits of seeking status within a system that prioritizes traditional models of gender complementarity.

Despite their criticism of fraternity parties, women in all tiers required women’s willingness to socialize in highly sexualized, male-dominated spaces. In the end, then, women with hybrid femininities -whose awareness of gendered power asymmetries was coupled with academic and professional ambition - could not dislodge men’s control over party spaces. 
Preprint of conditionally accepted manuscript. Forthcoming in Gender \& Society. 2020-09-21 Web version.

Women's complaints may even have allowed them to continue attending them: women could point to their ongoing complaints and critiques as a way to reconcile the tension they felt between wanting to partake in fraternity parties, on the one hand, and knowing fraternity parties reinforced male power and divisions among women, on the other.

It is important to recognize that sorority women's orientations to fraternity parties occurred within a context where they lacked power relative to fraternity men. Social-historical conditions, including antiquated regulations that prevent sorority women from hosting their own parties and ongoing pressure to embody hegemonic femininity, prompted sorority women to seek invitations to parties at fraternity houses.

Gendered processes are evident at the individual, interactional, and organizational levels (Armstrong et al. 2006; Martin 2004; Risman 2004). When these multiple levels are in symbiotic alignment, gender inequality is difficult to dislodge (Risman 2004). However, dynamics at one level influence dynamics at the other levels. This gives cause for optimism about the possibility of social transformation (Risman 2004). We hope that campus administrators and leaders could intervene at the institutional level to lessen the negative consequences of power asymmetries between men and women, and between women with different amounts of gender capital. For instance, more inclusive extracurricular programming and alcohol policies that allow partyoriented students a more aboveground party experience may be valuable (Wade et al. 2014; see Hirsch \& Khan 2020 for additional policy recommendations). Such policy changes could reduce the power of the "patriarchal bargain,” which requires women to enact strategies and coping mechanisms that maximize their well-being within the constraints of asymmetrical power relations with men (Kandiyoti 1988). 
Preprint of conditionally accepted manuscript. Forthcoming in Gender \& Society. 2020-09-21 Web version.

\section{BIBLIOGRAPHY}

Armstrong, Elizabeth, Laura Hamilton and Brian Sweeney. 2006. "Sexual Assault on Campus: A Multilevel, Integrative Approach to Party Rape." Social Problems 53(4):483-99.

Armstrong, Elizabeth and Laura Hamilton. 2013. Paying for the Party : How College Maintains Inequality. Cambridge, MA: Harvard University Press.

Bettie, Julie. 2003. Women without Class : Girls, Race, and Identity. Berkeley: University of California Press.

Bridges, Tristan and C.J. Pascoe. 2014. "Hybrid Masculinities: New Directions in the Sociology of Men and Masculinities." Sociology Compass 8(3):246-58.

Bridges, Tristan. 2009. "Gender Capital and Male Bodybuilders." Body \& Society 15(1):83-107.

Choo, Hae Yeon and Myra Marx Ferree. 2010. "Practicing Intersectionality in Sociological Research: A Critical Analysis of Inclusions, Interactions, and Institutions in the Study of Inequalities*." Sociological Theory 28(2):129-49.

Collins, Patricia Hill. 2000. Black Feminist Thought: Knowledge, Consciousness, and the Politics of Empowerment. New York: Routledge.

Connell, Raewyn. 1987. Gender and Power: Society, the Person, and Sexual Politics. Stanford, CA: Stanford University Press.

Connell, Raewyn. 1995. Masculinities. Berkeley: University of California Press.

Coser, Lewis. 1974. Greedy Institutions; Patterns of Undivided Commitment. New York: Free Press.

Cousin, Bruno, Shamus Khan and Ashley Mears. 2018. "Theoretical and Methodological Pathways for Research on Elites." Socio-Economic Review 16(2):225-49. 
Preprint of conditionally accepted manuscript. Forthcoming in Gender \& Society. 2020-09-21 Web version.

Demetriou, Demetrakis. 2001. "Connell’s Concept of Hegemonic Masculinity: A Critique." Theory and Society 30(3):337-61.

DeSantis, Alan. 2007. Inside Greek U.: Fraternities, Sororities, and the Pursuit of Pleasure, Power, and Prestige. Lexington, KY: University Press of Kentucky.

Deterding, Nicole and Mary Waters. 2018. "Flexible Coding of in-Depth Interviews: A TwentyFirst-Century Approach." Sociological Methods \& Research. Online first. https://doi.org/10.1177/0049124118799377.

Graber, Shane and Kelsey Whipple. 2019. "Yes to Bezique, No to Aqueduct: A Critical Discourse Analysis of How Us News Covers Sororities." Feminist Media Studies:1-16. Hamilton, Laura, Elizabeth A Armstrong, J Seeley and Elizabeth M Armstrong. 2019. "Hegemonic Femininities and Intersectional Domination." Sociological Theory 37(4):315-41.

Hamilton, Laura. 2014. The Revised MRS: Gender Complementarity at College. Gender \& Society 28(2): 236-264.

Hirsch, Jennifer and Shamus Khan. 2020. Sexual Citizens: A Landmark Study of Sex, Power, and Assault on Campus. New York: Norton.

Hughey, Matthew. 2010. "A Paradox of Participation: Nonwhites in White Sororities and Fraternities." Social Problems 57(4):653-79.

Ispa-Landa, Simone. 2013. "Gender, Race, and Justifications for Group Exclusion: Urban Black Students Bussed to Affluent Suburban Schools." Sociology of Education 86:218-33. Jozkowski, Kristen and Jacquelyn Wiersma-Mosley. 2017. "The Greek System: How Gender Inequality and Class Privilege Perpetuate Rape Culture." Family Relations 66(1):89-103.. Kandiyoti, Deniz. 1988. "Bargaining with Patriarchy." Gender \& Society 2(3):274-90. 
Preprint of conditionally accepted manuscript. Forthcoming in Gender \& Society. 2020-09-21 Web version.

Ken, Ivy. 2008. "Beyond the Intersection: A New Culinary Metaphor for Race-Class-Gender Studies." Sociological Theory 26(2):152-72.

Khan, Shamus. 2010. Privilege: The Making of an Adolescent Elite at St. Paul's School. Princeton, NJ: Princeton University Press.

Lamont, Michèle. 2012. "Toward a Comparative Sociology of Valuation and Evaluation." Annual Review of Sociology 38(1):201-21.

Martin, Patricia. 2004. “Gender as a Social Institution.” Social Forces 82: 1249-73.

Messerschmidt, James. 2016. Masculinities in the Making: From the Local to the Global. Lanham, MD: Rowman \& Littlefield.

Myers, Kristen. 2004. “Ladies First: Race, Class, and the Contradictions of a Powerful Femininity.” Sociological Spectrum (24): 11-41.

Quadlin, Natasha. 2016. "Gender and Time Use in College: Converging or Diverging Pathways?" Gender \& Society 30(2):361-85.

Renold, Emma, and Alexandra Allan. "Bright and beautiful: High achieving girls, ambivalent femininities, and the feminization of success in the primary school." Discourse: Studies in the Cultural Politics of Education 27.4 (2006): 457-473.

Risman, Barbara. 2004. “Gender as Social Structure: Theory Wrestling with Activism.” Gender \& Society 18: 429-50.

Risman, Barbara. 2018. Where the Millennials Will Take Us: A New Generation Wrestles with the Gender Structure. New York: Oxford.

Schippers, Mimi. 2007. "Recovering the Feminine Other: Masculinity, Femininity, and Gender Hegemony." Theory and Society 36(1):85-102. 
Preprint of conditionally accepted manuscript. Forthcoming in Gender \& Society. 2020-09-21 Web version.

Small, Mario. 2011. "How to Conduct a Mixed Methods Study: Recent Trends in a Rapidly Growing Literature." Annual Review of Sociology 37(1):57-86.

Stuber, Jenny, Joshua Klugman and Caitlin Daniel. 2011. "Gender, Social Class, and Exclusion: Collegiate Peer Cultures and Social Reproduction." Sociological Perspectives 54(3):43151.

Wade, Lisa, Brian Sweeney, Amelia Derr, Michael Messner and Carol Burke. 2014. "Ruling out Rape." Contexts 13(2):16-25.

Wade, Lisa. 2017. American Hookup: The New Culture of Sex on Campus: New York: Norton. 
Preprint of conditionally accepted manuscript. Forthcoming in Gender \& Society. 2020-09-21 Web version.

TABLE 1: Sorority House Chapters and Tiers

\begin{tabular}{|l|c|}
\hline \multicolumn{1}{|c|}{$\begin{array}{c}\text { Chapter } \\
\text { Pseudonym }\end{array}$} & Tier Ranking \\
\hline Blue & Bottom \\
\hline Purple & Bottom \\
\hline Red & Bottom \\
\hline Orange & Middle \\
\hline Yellow & Middle \\
\hline Violet & Middle \\
\hline Pink & Middle \\
\hline Turquoise & Middle \\
\hline Magenta & Middle \\
\hline Gray & Top \\
\hline Green & Top \\
\hline Brown & Top \\
\hline
\end{tabular}


Preprint of conditionally accepted manuscript. Forthcoming in Gender \& Society. 2020-09-21 Web version.

TABLE 2: Participant Information: Cohort 1 (interviewed Spring 2017-19)

\begin{tabular}{|c|c|c|c|c|c|}
\hline Name & $\begin{array}{l}\text { Interview } \\
\text { Waves } \\
\text { Completed }\end{array}$ & Chapter & Tier & Race & $\begin{array}{l}\text { Estimated* } \\
\text { Annual } \\
\text { Household } \\
\text { Income }\end{array}$ \\
\hline Abigail & 2 & Magenta & Middle & White & $\$ 25,000-\$ 49,999$ \\
\hline Alexis & 3 & Violet & Middle & White & $\$ 50,000-\$ 99,999$ \\
\hline Allison & 2 & Blue & Bottom & Asian & $\begin{array}{l}\$ 250,000- \\
\$ 350,000\end{array}$ \\
\hline Alyssa & 2 & Yellow & Middle & White & $\begin{array}{l}\$ 100,000- \\
\$ 149,999\end{array}$ \\
\hline Amy & 3 & Blue & Bottom & White & $\begin{array}{l}\$ 100,000- \\
\$ 149,999\end{array}$ \\
\hline Ariana & 2 & Orange & Middle & White & $\begin{array}{l}\$ 150,000- \\
\$ 249,999\end{array}$ \\
\hline Arshia & 2 & Blue & Middle & Asian & $\begin{array}{l}\$ 150,000- \\
\$ 249,999\end{array}$ \\
\hline Chloe & 2 & Orange & Middle & Asian & $\begin{array}{l}\$ 250,000- \\
\$ 350,000\end{array}$ \\
\hline Claire & 2 & Brown & Top & White & $\begin{array}{l}\$ 150,000- \\
\$ 249,999\end{array}$ \\
\hline Elizabeth & 3 & Blue & Bottom & White & $\begin{array}{l}\$ 250,000- \\
\$ 350,000\end{array}$ \\
\hline Terah & 3 & Orange & Middle & Asian & $\begin{array}{l}\$ 250,000- \\
\$ 350,000\end{array}$ \\
\hline Evelyn & 3 & Magenta & Middle & White & $\begin{array}{l}\$ 350,000- \\
\$ 500,000\end{array}$ \\
\hline Betty & 3 & Green & Top & White & $\$ 50,000-\$ 99,999$ \\
\hline Harper & 3 & Gray & Top & $\begin{array}{l}\text { Hispanic or } \\
\text { Latino }\end{array}$ & $\begin{array}{l}\$ 100,000- \\
\$ 149,999\end{array}$ \\
\hline Helen & 3 & Magenta & Middle & White & $\begin{array}{l}\$ 100,000- \\
\$ 149,999\end{array}$ \\
\hline Isabelle & 3 & Violet & Middle & White & $\begin{array}{l}\$ 100,000- \\
\$ 149,999\end{array}$ \\
\hline Jane & 3 & Purple & Bottom & White & $\begin{array}{l}\$ 100,000- \\
\$ 149,999\end{array}$ \\
\hline Jenny & 3 & Violet & Middle & White & $\$ 1 M-\$ 2 M$ \\
\hline Katrina & 3 & Magenta & Middle & Asian & $\begin{array}{l}\$ 100,000- \\
\$ 149,999\end{array}$ \\
\hline Rose & 3 & Magenta & Middle & White & $\begin{array}{l}\$ 250,000- \\
\$ 350,000\end{array}$ \\
\hline Lea & 3 & Green & Top & White & $\begin{array}{l}\text { Greater than } \\
\$ 350,000\end{array}$ \\
\hline
\end{tabular}


Preprint of conditionally accepted manuscript. Forthcoming in Gender \& Society. 2020-09-21 Web version.

\begin{tabular}{|c|c|c|c|c|c|}
\hline Leslie & 2 & Blue & Bottom & Asian & $\begin{array}{l}\$ 100,000- \\
\$ 149,999\end{array}$ \\
\hline Lety & 3 & Blue & Bottom & $\begin{array}{l}\text { Hispanic or } \\
\text { Latino }\end{array}$ & $\$ 50,000-\$ 99,999$ \\
\hline Lilla & 3 & Purple & Bottom & $\begin{array}{l}\text { Hispanic or } \\
\text { Latino }\end{array}$ & $\$ 1 M-\$ 2 M$ \\
\hline Flora & 3 & Gray & Top & Asian & $\begin{array}{l}\$ 100,000- \\
\$ 149,999\end{array}$ \\
\hline Melody & 3 & Magenta & Middle & $\begin{array}{l}\text { Other - White } \\
\text { \& Asian }\end{array}$ & $\begin{array}{l}\$ 100,000- \\
\$ 149,999\end{array}$ \\
\hline Molly & 3 & Brown & Top & White & Greater than \$5M \\
\hline Naomi & 3 & Orange & Middle & White & $\$ 50,000-\$ 99,999$ \\
\hline Natalie & 2 & Brown & Top & $\begin{array}{l}\text { Hispanic or } \\
\text { Latino }\end{array}$ & $\$ 2 M-\$ 5 M$ \\
\hline Nicole & 3 & Pink & Middle & Asian & $\$ 50,000-\$ 99,999$ \\
\hline Sandra & 3 & Violet & Middle & White & $\begin{array}{l}\$ 100,000- \\
\$ 149,999\end{array}$ \\
\hline Pearl & 3 & Purple & Bottom & White & $\begin{array}{l}\$ 150,000- \\
\$ 249,999\end{array}$ \\
\hline Sally & 3 & Purple & Bottom & White & $\begin{array}{l}\$ 150,000- \\
\$ 249,999\end{array}$ \\
\hline Samantha & 3 & Purple & Bottom & White & $\$ 25,000-\$ 49,999$ \\
\hline Susan & 3 & Green & Top & White & $\begin{array}{l}\text { Greater than } \\
\$ 350,000\end{array}$ \\
\hline Zora & 2 & Yellow & Middle & White & $\$ 500,000-\$ 1 M$ \\
\hline Zoe & 3 & Red & Bottom & White & $\begin{array}{l}\$ 250,000- \\
\$ 350,000\end{array}$ \\
\hline
\end{tabular}

${ }^{*}$ Cohort 1 participants were asked to provide a self-reported estimate of their families' annual household income, before taxes, via a survey.

*n (Cohort $\mathbf{1})=37$ participants 
Preprint of conditionally accepted manuscript. Forthcoming in Gender \& Society. 2020-09-21 Web version.

TABLE 3: Participant Information: Cohort 2 (interviewed Spring 2019)

\begin{tabular}{|c|c|c|c|c|c|c|}
\hline Name & $\begin{array}{l}\text { Waves } \\
\text { Completed }\end{array}$ & Chapter & Tier & Race & $\begin{array}{l}\text { Parent/Guardian } \\
1 \text { Estimated } \\
\text { Annual Income* }\end{array}$ & $\begin{array}{l}\text { Parent/Guardian } \\
2 \text { Estimated } \\
\text { Annual Income* }\end{array}$ \\
\hline Amber & 1 & Turquoise & Middle & White & Less than $\$ 50,000$ & $\$ 250,000-\$ 500,000$ \\
\hline Arisa & 1 & Magenta & Middle & Asian & $\$ 75,000-\$ 100,000$ & Less than $\$ 50,000$ \\
\hline Brianna & 1 & Turquoise & Middle & White & $\$ 100,000-\$ 150,000$ & Less than $\$ 50,000$ \\
\hline Courtney & 1 & Turquoise & Middle & White & $\$ 100,000-\$ 150,000$ & $\$ 100,000-\$ 150,000$ \\
\hline Deborah & 1 & Brown & Top & Asian & Less than $\$ 50,000$ & $\$ 250,000-\$ 500,000$ \\
\hline Heather & 1 & Violet & Middle & White & Less than $\$ 50,000$ & $\$ 250,000-\$ 500,000$ \\
\hline Kirby & 1 & Violet & Middle & Asian & Less than $\$ 50,000$ & Less than $\$ 50,000$ \\
\hline Lynn & 1 & Turquoise & Middle & $\begin{array}{l}\text { Other - } \\
\text { White \& } \\
\text { Asian }\end{array}$ & $\$ 50,000-\$ 75,000$ & $\$ 100,000-\$ 150,000$ \\
\hline Melanie & 1 & Pink & Middle & $\begin{array}{l}\text { Hispanic } \\
\text { or } \\
\text { Latino }\end{array}$ & $\$ 75,000-\$ 100,000$ & Less than $\$ 50,000$ \\
\hline Melissa & 1 & Orange & Middle & $\begin{array}{l}\text { Hispanic } \\
\text { or } \\
\text { Latino }\end{array}$ & $\$ 1 M-\$ 2 M$ & Less than $\$ 50,000$ \\
\hline Rachael & 1 & Brown & Top & $\begin{array}{l}\text { Hispanic } \\
\text { or } \\
\text { Latino }\end{array}$ & $\$ 75,000-\$ 100,000$ & $\$ 100,000-\$ 150,000$ \\
\hline Clara & 1 & Orange & Middle & Asian & Less than $\$ 50,000$ & Less than $\$ 50,000$ \\
\hline Reyna & 1 & Pink & Middle & White & $\$ 100,000-\$ 150,000$ & $\mathrm{~N} / \mathrm{A}$ \\
\hline Ruth & 1 & Pink & Middle & White & $\$ 100,000-\$ 150,000$ & $\$ 150,000-\$ 250,000$ \\
\hline Teagan & 1 & Turquoise & Middle & White & Less than $\$ 50,000$ & $\$ 250,000-\$ 500,000$ \\
\hline Vanessa & 1 & Orange & Middle & White & $\$ 100,000-\$ 150,000$ & $\$ 100,000-\$ 150,000$ \\
\hline
\end{tabular}

*Cohort 2 participants were asked to provide a self-reported estimate of each parents'/guardians' income, before taxes, via a survey. Cohort 2 participants were not asked to provide an estimate of total annual household income. That is why we include their information in two separate tables.

I. $\mathbf{n}$ (Cohort 2) $=16$ participants 